\title{
Sunflower (Helianthus annuus L.) genetic resources, production and researches in Turkey ${ }^{\text {is }}$
}

\author{
Ahmet Semsettin Tan ${ }^{1, *}$ and Yalcin Kaya ${ }^{2}$ \\ ${ }^{1}$ Sunflower Breeder and Geneticist, Menemen, Izmir, Turkey \\ 2 Trakya University, Dept. of Genetics and Bioengineering, Edirme, Turkey
}

Received 12 September 2018 - Accepted 30 January 2019

\begin{abstract}
Sunflower is one of the leading oilseed crops and it is widely grown in the Thrace region of Turkey. In 2017, in Turkey as a whole, oilseed and confectionary sunflowers were grown on 779.622 ha with a total production of $1964385 \mathrm{t}$ of seed, and average yields of $2.64 \mathrm{tha}^{-1}$ for oilseed and $1.67 \mathrm{tha}^{-1}$ for confectionary types. Turkey is one of the important countries for crop diversity and has been described as a microcenter for some crops, which originated in different parts of the world. Landraces of sunflower (Helianthus annuus L.) show significant diversity in Turkey and have been collected in the framework of the "National Industrial Plant Genetic Resources Project" (NPGRP). Nine hundred and thirty two oilseed and confectionary sunflower accessions are in longterm conservation in the National Seed Gene Bank of Turkey. The mission of the National Sunflower Research Project is to develop improved germplasm and hybrid varieties by conventional and biotechnical breeding techniques in Turkey. New germplasm and breeding lines have been developed to improve oilseed and confectionary sunflower hybrids with desired characters including high yield and oil quality, resistance to diseases such as: Plasmopara halstedii (Farl.) Berl de Toni., Puccinia helianthi Schw., and Orobanche cumana Walr. Adverse conditions are also taken under consideration. These studies are integrated with agronomic and other related research.
\end{abstract}

Keywords: sunflower / Helianthus annuus L. / production / landraces / Turkey

Résumé - Tournesol (Helianthus annuus L.) en Turquie: ressources génétiques, production et recherche. En Turquie, le tournesol est l'une des principales cultures d'oléagineux et est principalement cultivé dans la région de Thrace. En 2017, les tournesols oléagineux et de bouche ont été cultivées sur 779622 hectares en Turquie pour une récolte de 1964385 t et des rendements moyens de 2640 t/ha pour le premier et 1670 t/ha pour le second. La Turquie est l'un des principaux pays pour la diversité des cultures et est décrite comme un microcentre pour certaines cultures originaires de différentes régions du monde. Les variétés du tournesol (Helianthus annuus L.) présentent également une diversité importante en Turquie. Les variétés de pays de tournesol ont été rassemblées dans le cadre du «Projet national de ressources génétiques pour les cultures industrielles » (National Industrial Plant Genetic Resources Project, NPGRP). Neuf cent trente-deux entrées (932 entrées) de tournesol oléagineux et de bouche sont en conservation à long terme à la Banque nationale de ressources génétiques de Turquie. Le projet de recherche national sur le tournesol a pour mission de développer du matériel génétique amélioré au moyen de techniques de sélection conventionnelles et biotechnologiques pour la région de Thrace et d'autres zones de production en Turquie. De nouveaux germplasmes et lignées parentales ont été mis au point pour améliorer les variétés hybrides oléagineux et de bouches avec les caractères recherchés: rendement élevé et huile de bonne qualité, résistance aux maladies telles que Plasmopara halstedii (Farl.) Berl de Toni., Puccinia helianthi Schw. et Orobanche cumana Walr. Les comportements en conditions défavorables sont également pris en compte. Ces études sont également intégrées à des recherches en agronomie et d'autres sujets connexes.

Mots clés : tournesol / Helianthus annuus L. / production / variétés de pays / Turquie

\footnotetext{
Contribution to the Topical Issue "The oil \& protein crop supply chain in Eastern Europe / La filière oléoprotéagineuse en Europe de l'Est"

*Correspondence: a_s_tan@hotmail.com
} 


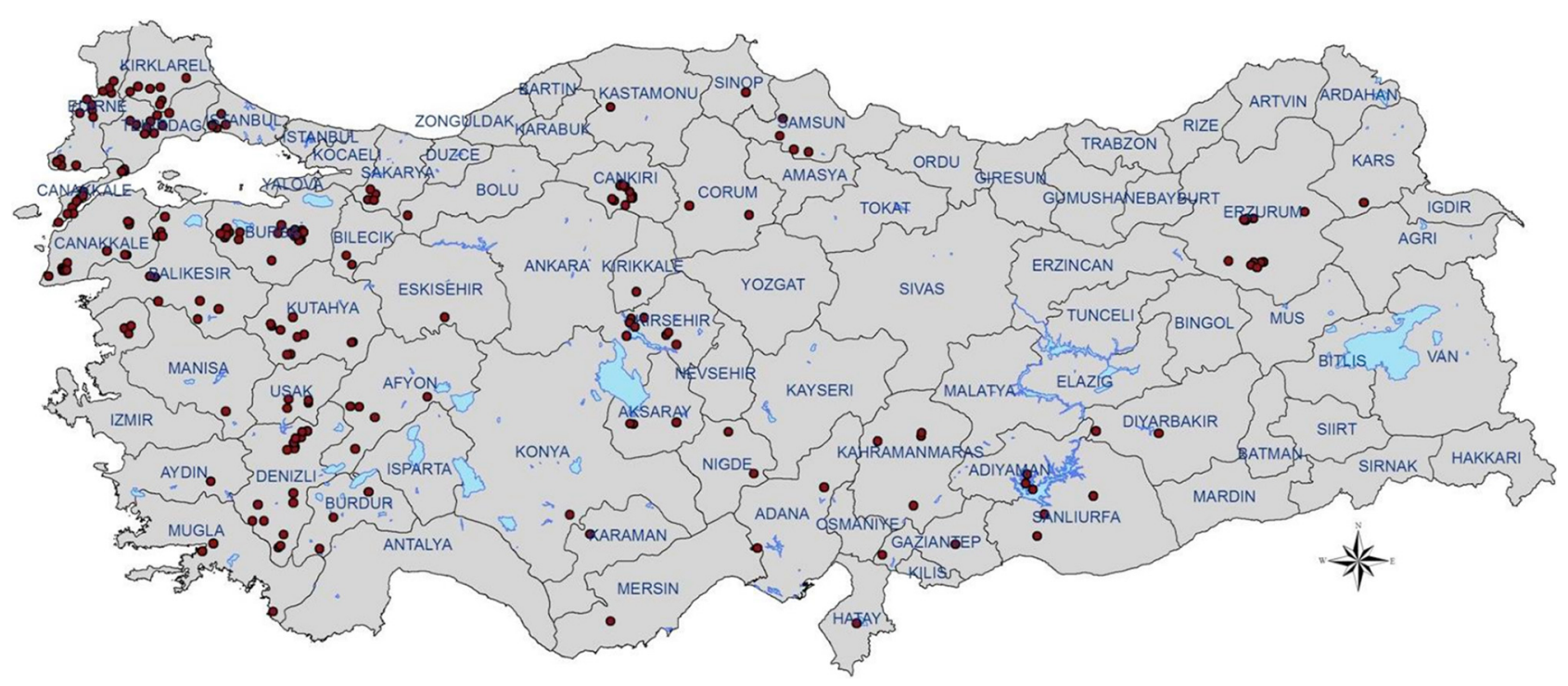

Fig. 1. Collection sites of sunflower land races in Turkey.

\section{Introduction}

Turkey is an important country concerning plant genetic resources and center of origin or micro gene center for several crop species (Harlan, 1951) that did not originate in the country, but shows diversity for many characteristics (Tan, 2009; Tan, 2010a, b; Karagoz et al., 2010). Two centers of origin (Mediterranean and Near Eastern) overlap in Anatolia. About 3700 of the 11707 plant taxa found there are endemic to Turkey (Guner et al., 2012). The National Industrial Crops Genetic Resources Research Project aims to survey, collect, conserve long term, characterize, regenerate and utilize the industrial crop genetic resources of Turkey. This collection is a source of germplasm to be used in breeding programs.

Helianthus annuus L. originated in North America, where wild sunflowers provide important genetic diversity for crop improvement (Heiser et al., 1969; Heiser, 1978; Putt, 1978; Zeven and de Wet, 1982; Miller, 1987; Gobbelen et al., 1989; Schneiter, 1997). Landraces are also important sources of genetic variability, because they have adapted to local environments as a result of natural selections over centuries. Thus, the evaluation of existing confectionary and oilseed sunflower land races is essential for increased utilization. Characterization studies indicated that confectionary land races are highly variable for morphological characters (Tan, 1993; Tan, 2002; Tan, 2010a, b; Tan and Tan, 2010; 2011; 2012; Tan et al., 2013a, b; Tan et al., 2016a, c; Tan et al., 2017b; Altunok Memiş, 2018; Altunok Memiş et al., 2018).

\section{Sunflower genetic resources in Turkey}

Crop genetic bases became narrowed since landraces were replaced by modern cultivars (Tanksley and McCouch, 1997). Therefore, in the framework of National Plant Genetic Resources Program (NPGRP), since the 1960s, Turkish landraces of many species have been surveyed, identified then collected before they disappeared and conserved at the
National Seed Gene Bank at the Aegean Agricultural Research Institute (AARI) in Izmir, Turkey (Tan, 2000; Tan, 2010b). The sunflower genetic resources collections are included in this seed bank as part of the "Industrial Crops Genetic Resources Project" (Tan and Tan, 1998a, b; Tan, 2000; Tan, 2009; Tan and Tan, 2010, Tan, 2010a, b; Tan and Tan, 2011; 2012; Tan et al., 2013a, b; Tan et al., 2016a, c; Tan et al., 2017c).

These landraces or primitive cultivars are very important sources of genetic diversity, with their adaptability to local environments as a result of natural or farmer selection over centuries. To date, over 932 oilseed and confectionary sunflower accessions collected from sunflower fields, farmer storage and markets are long term ex situ conserved at the National Seed Gene Bank of Turkey (Anonymous, 2017a; Altunok Memiş et al., 2018). Figure 1 shows the collection areas of sunflower land races in Turkey (Anonymous, 2017a; Tan et al., 2017c; Altunok Memiş, 2018).

The oilseed and confectionary sunflower genetic resources received from the National Seed Gene Bank of Turkey were observed for 43 morphological, phenological and technological characters identified by UPOV (Anonymous, 2000) and IBPGRI (IBPGR, 1985).

The data were evaluated by Principal Component Analysis (PCA), and Cluster Analysis and the eco-geographical distribution and agro-morphological variation of both oilseed and confectionary sunflower landraces at National Gene Bank have been published (Sneath and Sokal, 1973; Clifford and Stephenson, 1975; Tan, 1983). The distribution areas of sunflower samples showed significant variation within and between accessions. Distinct groupings were determined in principal components and the results of analyses exhibited broad morphological variation for land races (Tan and Tan, 2010, 2012; Tan et al., 2013a, b; Altunok Memiş, 2018).

This genetic diversity and its characterization are very important for hybrid sunflower variety breeding because parental lines with diverse origin have higher potential heterosis, then hybrids made from closely related parents (Kaya, 2010; Kaya, 2014a; Kaya, 2016). Thus, both 
A.S. Tan and Y. Kaya: OCL 2019, 26, 21

Table 1. Oilseed and confectionary sunflower production values in Turkey (Anonymous, 2017b).

\begin{tabular}{|c|c|c|c|c|c|c|c|c|}
\hline Year & \multicolumn{3}{|c|}{ Production area $(\mathrm{da})$} & \multicolumn{3}{|c|}{ Production (Metric tons) } & \multicolumn{2}{|c|}{ Yield (kg/da) } \\
\hline 2004 & 4800000 & 700000 & 5500000 & 800000 & 100000 & 900000 & 167 & 143 \\
\hline 2006 & 5100000 & 754000 & 5854000 & 1010000 & 108000 & 1118000 & 198 & 143 \\
\hline 2007 & 4857000 & 689778 & 5546778 & 770000 & 84407 & 854407 & 159 & 122 \\
\hline 2008 & 5100000 & 700000 & 5800000 & 900387 & 91613 & 992000 & 177 & 131 \\
\hline 2010 & 5514000 & 900000 & 6414000 & 1170000 & 150000 & 1320000 & 212 & 167 \\
\hline 2011 & 5560000 & 997000 & 6557000 & 1170000 & 165000 & 1335000 & 210 & 165 \\
\hline 2012 & 5046160 & 1000000 & 6046160 & 1200000 & 170000 & 1370000 & 238 & 170 \\
\hline 2013 & 5202600 & 895239 & 6097839 & 1380000 & 143000 & 1523000 & 265 & 160 \\
\hline 2014 & 5524651 & 1049925 & 6574576 & 1480000 & 157900 & 1637900 & 268 & 150 \\
\hline 2015 & 5689950 & 1163224 & 6853174 & 1500000 & 180700 & 1680700 & 264 & 155 \\
\hline
\end{tabular}

Table 2. Oilseed sunflower production values in major provinces of Turkey in 2016 (Anonymous, 2017b).

\begin{tabular}{llll}
\hline Provinces & $\begin{array}{l}\text { Production } \\
\text { area }(\mathrm{da})\end{array}$ & $\begin{array}{l}\text { Production } \\
\text { (Metric tons) }\end{array}$ & $\begin{array}{l}\text { Yield } \\
(\mathrm{kg} / \mathrm{da})\end{array}$ \\
\hline Tekirdag & 1420265 & 283838 & 200 \\
Edirne & 988286 & 222064 & 225 \\
Kirklareli & 782569 & 170278 & 218 \\
Adana & 539542 & 166524 & 309 \\
Konya & 526832 & 205274 & 390 \\
Corum & 243244 & 56048 & 230 \\
Istanbul & 171484 & 37544 & 219 \\
Canakkale & 170421 & 39097 & 229 \\
Balikesir & 157148 & 30555 & 194 \\
Samsun & 151901 & 35546 & 234 \\
Tokat & 137141 & 39306 & 287 \\
Amasya & 122547 & 33122 & 270 \\
Bursa & 99564 & 23172 & 233 \\
\hline
\end{tabular}

confectionary and oilseed sunflower land races have been evaluated and utilized in breeding programs at AARI and TARI (Thrace Agricultural Research Institute).

\section{Sunflower production in Turkey}

An increasing world population makes necessary increased availability of human foods. Vegetable oils are an important source of energy. Production of sunflowers with high yield, oil percentage and oil quality will help to reduce the oilseed production gap in Turkey, which is one of the leading countries for sunflower production. Data presented in Table 1 shows that oilseed and confectionary sunflowers were grown on 779622 ha producing with $1964385 \mathrm{t}$ of seed and an average yield of $2.64 \mathrm{t} /$ ha oilseed and $1.67 \mathrm{t} /$ ha for confectionary types in 2017 (Anonymous, 2017b).

Hybrid varieties constitute approximately $95 \%$ of production, but farmers generally prefer to use low yielding landraces
Table 3. Confectionary sunflower production values in major provinces of Turkey in 2016 (Anonymous, 2017b).

\begin{tabular}{llll}
\hline Provinces & $\begin{array}{l}\text { Production } \\
\text { area }(\mathrm{da})\end{array}$ & $\begin{array}{l}\text { Production } \\
\text { (Metric tons) }\end{array}$ & $\begin{array}{l}\text { Yield } \\
(\mathrm{kg} / \mathrm{da})\end{array}$ \\
\hline Ankara & 258217 & 27799 & 108 \\
Denizli & 159370 & 32155 & 202 \\
Kayseri & 97086 & 20341 & 210 \\
Kırkkkale & 82035 & 6004 & 73 \\
Yozgat & 78802 & 7906 & 100 \\
Kahramanmaraş & 63100 & 19515 & 309 \\
Kırsehir & 48650 & 4681 & 96 \\
Aksaray & 47660 & 10323 & 217 \\
Bursa & 37680 & 10592 & 281 \\
Afyon & 28560 & 3564 & 125 \\
Konya & 25128 & 7038 & 280 \\
Eskisehir & 19058 & 4306 & 226 \\
Erzurum & 16504 & 3938 & 239 \\
Karaman & 15418 & 1402 & 109 \\
Bilecik & 14910 & 2330 & 156 \\
Corum & 11528 & 3021 & 262 \\
\hline
\end{tabular}

when they grow confectionary sunflowers. Major provinces producing oilseed and confectionary sunflower in 2016 are given in Tables 2 and 3.

The Thrace region produces $49.3 \%$ of Turkish oilseed sunflowers in Tekirdag, Edirne, Kirklareli, and Canakkale provinces. This is followed by the Mediterranean, Central Anatolia, Southeastern Anatolia, Black Sea, South Marmara and Aegean regions. These provinces produce a total of $39.7 \%$ of production (Anonymous, 2017b). Linoleic (conventional) types represent $97 \%$ of sunflower production, high oleic types $3 \%$. The main confectionary seed production areas are in Central Anatolia and the Aegean Region (Anonymous, 2017b).

Sunflower contributes 1800000 tons to the total production of 2700000 tons of all oilseed crops in Turkey. This production is not sufficient to cover local oil consumption, 
Table 4. Sunflower oil export and import values of Turkey (Anonymous, 2017c).

\begin{tabular}{lllll}
\hline Years & \multicolumn{2}{c}{ Import } & & \multicolumn{1}{c}{ Export } \\
\cline { 2 - 3 } & Metric tons & \multicolumn{1}{c}{ US \$ } & Metric tons \\
\hline 2007 & 163115 & 138039000 & 31906 & 36002000 \\
2008 & 411660 & 647095000 & 98714 & 164582000 \\
2009 & 323596 & 468305000 & 101432 & 110618000 \\
2010 & 223998 & 271020000 & 75886 & 100509000 \\
2011 & 469858 & 629068000 & 204872 & 338658000 \\
2012 & 742877 & 987295000 & 271257 & 416884000 \\
2013 & 625849 & 908122000 & 346256 & 496198000 \\
2014 & 812401 & 1177993000 & 665241 & 790130000 \\
2015 & 798170 & 1101230000 & 618525 & 680701000 \\
2016 & 738417 & 1015306000 & 600777 & 637448000 \\
\hline
\end{tabular}

Table 5. Sunflower seed export and import values of Turkey (Anonymous, 2017c).

\begin{tabular}{lllll}
\hline Years & \multicolumn{2}{c}{ Import } & & \multicolumn{1}{c}{ Export } \\
\cline { 2 - 3 } & Metric Ton & US \$ & Metric Ton \\
\hline 2007 & 596147 & 260166000 & 10052 & 7826 \\
2008 & 455995 & 365145000 & 16195 & 30277000 \\
2009 & 468277 & 240620000 & 21643 & 35054000 \\
2010 & 645607 & 348113000 & 32402 & 58912000 \\
2011 & 905686 & 589577000 & 56268 & 114321000 \\
2012 & 754162 & 443958000 & 34700 & 103301000 \\
2013 & 710843 & 474001000 & 33521 & 111730000 \\
2014 & 556909 & 406154000 & 35202 & 78875000 \\
2015 & 340192 & 237984000 & 48259 & 120887000 \\
2016 & 382263 & 263925000 & & \\
\hline
\end{tabular}

Table 6. Sunflower seed processing capacity and sunflower oil consumption in Turkey (Anonymous, 2017c).

\begin{tabular}{llllllll}
\hline & \multicolumn{7}{c}{1000 Metric tons /Years } \\
\cline { 2 - 8 } & 2009 & 2010 & 2011 & 2012 & 2013 & 2014 & 2015 \\
\hline Seed processing capacity & 1590 & 1730 & 1695 & 1640 & 1900 & 1560 & 1630 \\
Sunflower oil consumption & 650 & 726 & 846 & 825 & 870 & 827 & 876 \\
\hline
\end{tabular}

partly because, although 971000 tons of oilseed sunflower are used directly, 600777 tons are exported (Tab. 4). To cover the oilseed deficit, Turkey paid $3.5 \times 10^{9}$ US $\$$ in 2016 to import oilseed and its derivatives, including 738417 tons of sunflower oil at a cost of $1.015 \times 10^{9} \$$ (Tab. 4). While 382263 tons of oilseed sunflower were imported with a value of $264 \times 10^{6} \$ ; 48259$ tons were exported (Tab. 5). It would be useful to increase, perhaps even double sunflower production in Turkey.

Turkey oil seed processing capacity is 1750000 tons but only $55 \%$ of the capacity of the 110 oil plants is utilized. Seed processing capacity and sunflower oil consumption in Turkey are given in Table 6 . Turkish refinery capacity is 4 million tons per year, but the utilization rate of the existing 110 facilities was $70 \%$ in 2016 (Anonymous, 2017c). The production of additional oil seeds would create added value. There are some additional potential sunflower production areas such as
Aegean Region and South East Anatolia with suitable ecological conditions for both main and second crop sunflower production in Turkey.

Turkey imports the oilseed sunflower seeds mainly from Bulgaria, Ukraine, Romania, Russia and Moldova. On the other hand, almost half of the raw sunflower oil import is from Ukraine, while the other part is from Russia, Argentina, Romania and Bulgaria. The most exported countries of refined sunflower oil are Iraq, Syria, Lebanon and Thailand (Anonymous, 2017c).

\section{Sunflower research in Turkey}

The mission of the "National Sunflower Research Projects" at TARI and AARI, and the other Agricultural Research Institutes in Turkey is to breed well adapted and high 
yielding varieties, and to develop knowledge and technology for the Turkish sunflower industry. Research is conducted to develop sunflower varieties with improved yield, oil quality, resistance to diseases such as downy mildew [(Plasmopara halstedii Farl de Toni)], rust (Puccinia helianthi Schw.), Sclerotinia, Rhizopus, Botrytis Macrophomina and broomrape (Orobanche sp.), other desired characters and adverse conditions (Tan, 1993; Kaya et al., 2004; Kaya and Evci, 2007; Kaya et al., 2009; Kaya, 2010; Tan, 2010a, b, c; Kaya et al., 2013, 2014; Kaya, 2016).

In Turkey, the main constraints for sunflower are attacks by broomrape and downy mildew (DM) but resistance is available to both parasites. Sunflower rust races have been identified under field conditions (Kaya et al., 2004; Kaya and Evci, 2007; Kaya et al., 2009; Tan, 2010a, b, c; Tan, 2010a; b; Kaya et al., 2012, 2013, 2014; Tan, 2014; Tan et al., 2016a, b; Tan et al., $2017 \mathrm{a}, \mathrm{b})$.

To date, oilseed and confectionary sunflower open pollinated variety, parental lines (CMS, maintainer, and restorer lines) and hybrid varieties have been developed and evaluated in yield trials under main and catch crop production seasons. Variety performance tests and yield trials indicated that sunflower can give with satisfactory yield performance (2.50-5.5 t/ha) in both seasons in Thrace, Aegean, and Mediterranean Regions of Turkey (Kaya, 2010; Tan, 2010a, b; Kaya, 2014b; Tan, 2014; Tan et al., 2016b; Kaya, 2016; Tan et al., 2017a, b). The Aegean Region that has suitable ecological conditions for both cropping systems should be considered for sunflower production, in order to decrease the vegetable oil gap in Turkey.

High oleic and herbicide resistant (IMI and SU groups) sunflower varieties are being developed. There are research programs to develop oilseed and confectionary sunflowers for both main and catch crop production seasons. Sunflower germplasm has been developed from sources such as cultivars and breeding populations and tested for general and specific combining ability. Inbred lines, candidate and commercial varieties are evaluated in preliminary and yield trials on a regional basis for both main and catch production seasons in the Aegean Region and other parts in Turkey. In addition, agronomic studies are made on effects of sowing date, plant population, fertilization, irrigation and honeybee pollination on seed yield, oil content, oil quality, silage quality and other plant characteristics.

There is a lack of certified confectionary seed production with desired quality for this type of crop. Consequently, land races are generally used for confectionary sunflower production in Turkey. However, they are not suitable for combine-harvesting because they are not uniform in terms of plant height and physiological maturity (Tan, 2010b; Tan and Tan, 2010). New high yielding oilseed and confectionary sunflower hybrids have been improved and registered for the direct benefit of the agricultural sector and increased sunflower production in the country (Kaya, 2010; Tan, 2010a, b; Aldemir et al., 2016; Altunok et al., 2016; Tan et al., 2016b, Tan et al., 2017a, b).

New high yielding oilseed and confectionary sunflower hybrids have been improved and registered for the direct benefit of the agricultural sector and increased sunflower production in the country.

\section{Conclusion}

Sunflower is one of the main oilseed crops that contribute to the economy of Turkey for both human and animal nutrition, creating employment and internal and external trade. Production needs to be increased by breeding high yielding varieties tolerant and or resistant to biological and physiological constraints. Sunflower landraces having diversity will also contribute improving high yielding oilseed and confectionary sunflower hybrids.

\section{References}

Aldemir M, Tan AS, Altunok A. 2016. Performance of some confectionary sunflower (Helianthus annuus L.) varieties in Aegean Region of Turkey, 19th International Sunflower Conference, Edirne, Turkey, 29 May-3 June 2016, pp. 548-555.

Altunok A, Tan AS, Aldemir M, et al. 2016. Performance of some oilseed sunflower (Helianthus annuus L.) varieties in Aegean Region of Turkey, 19th International Sunflower Conference, Edirne, Turkey, 29 May-3 June 2016, pp. 535-547.

Altunok Memiş AA. 2018. Türkiye Yağlık Ve Çerezlik Ayçiçeği (Helianthus annuus L.) Genetik Kaynaklarının Karakterizasyonu ve Değerlendirilmesi. Doktora Tezi. Ege Üniv. Zir. Fak. Tarla Bitkilreri Bölümü. Borova, İzmir.

Altunok Memiş A, Aldemir M, et al. 2018. Endüstri Bitkileri Genetik Kaynakları Araştırma Projesi. Proje Sonuç Raporu (2014-2018). Ege Tarımsal Araştırma Enstitüsü Müdürlüğü, Menemen, İzmir.

Anonymous. 2000. UPOV Guidelines for the conduct of tests for distinctness, Uniformity and stability, sunflower (Helianthus annuus L.). TG/81/6. Available from http://www.upov.int/edocs/ tgdocs/en/tg081.pdf.

Anonymous. 2017a. Database of documentation project of seed gene Bank of AARI in Turkey. Menemen, Izmir/Turkey: Aegean Agricultural Research Institute: .

Anonymous. 2017b. TUIK. Turkish Statistical Institute. Crop Production Statistics. http://www.tuik.gov.tr/.

Anonymous. 2017c. Association of vegetable oil industries database (Bitkisel Yă̆ Sanayicileri Derneği Verileri). Available from https://www.bysd.org.tr/Default.aspx/.

Clifford HT, Stephenson W. 1975. An introduction to numerical classification. New York: Academic Press.

Gobbelen G, Downey RK, Ashri A. 1989. Oil crops of the world: Their breeding and utilization. McGraw-Hill Pub. Co.

Guner A, Aslan S, Ekim T, Vural M, Babaç MT. 2012. Türkiye Bitkileri Listesi (Damarlı Bitkiler). Nezahat Gökyiğit Botanik Bahçesi ve Flora Araştırmaları Derneği Yayını. İstanbul.

Harlan JR. 1951. Anatomy of gene centers. Am Nat 85: 97-103.

Heiser CB Jr, Smith DM, Clevenger SB, Martin WC Jr. 1969. The North american Sunflowers (Helianthus). Mem Torrey Bot Club 22(3): 1-218.

Heiser CB Jr. 1978. Taxsonomy of Helianthus and origin of domesticated sunflower. In: Fehr W, ed. Sunflower sci. and technology. Agronomy 19: 31-53.

IBPGR. 1985. Sunflower descriptors. Rome, Italy: International board for plant genetic resources (IBPGR).

Karagoz A, Zencirci N, Tan A, et al. 2010. Conservation and utilization of plant genetic resources. Proc. of Turkish Agicultural Engineering VII. Techical Congress. 11-15 January, Ankara Turkey. 1: 155-177. 
Kaya Y. 2010. Public sunflower breeding in Turkey and future directions. Plant Sci. (Rastenievudni Naouki) 47(1): 7-13.

Kaya Y. Sunflower. In: Pratap A, ed. Alien gene transfer in crop plants, 2. Springer Press, 2014a, pp. 281-315.

Kaya Y. 2014b. Sunflower production in Balkan region: Current situation and future prospects. Agric For 60(4): 95-101.

Kaya Y, Evci G. 2007. Herbicide resistance in sunflower (Helianthus annuus L.). International Research Conference, Plant Genetic Stocks. The basis of agriculture of today, June 13-14, Plovdiv, Bulgaria, Vol. 2: 45-47.

Kaya Y. 2016. Sunflower in breeding oilseed crops for sustainable production. Elsevier Inc. Available from http://dx.doi.org/ 10.1016/B978-0-12-801309-0.00004-5.

Kaya Y, Evci G, Pekcan V, Gucer T. 2004. Determining new broomrape-infested areas, resistant lines and hybrids in Trakya region of Turkey. Helia 27(40): 211-218.

Kaya Y, Evci G, Pekcan V, Gucer T, Yilmaz MI, 2009. Evaluation of broomrape resistance in sunflower hybrids. Helia 32(51): 161-169.

Kaya Y, Jocic S, Miladinovic D. Sunflower. In: Gupta SK, ed. Technological innovations in major world oil crops, 1. New York: Springer Press, 2012, pp. 85-129

Kaya Y, Evci G, Pekcan V, Yilmaz MI. 2013. Clearfield technology in sunflower and developing herbicide resistance sunflower hybrids. Soil-Water J 2(2): 1713-1720.

Kaya Y, Evci G, Pekcan V, V, Yilmaz MI. Broomrape resistance breeding in sunflower: A case study in Turkey. Proceedings of the Third International Symposium on Broomrape (Orobanche spp.) in Sunflower, June 3-6. Cordoba: New York, 2014, pp. 194-199.

Miller JF. Sunflower Vol: 2. In: Fehr W, ed. Principle of cultivar development. NY: Macmillan Pub. Co, 1987, pp. 626-668.

Putt ED. 1978. History and present word status. In: Carter JF, ed. Sunflower science and technology. Madison, Wl: American Society of Agronomy, pp. 1-29.

Schneiter AA (Ed.). 1997. Sunflower science and technology. Am Soc Agron 35. Madison, Wisconsin, USA.

Sneath PHA, Sokal RR. 1973. Numerical taxonomy. The principles and practice of numerical classification. San Fransisco: Freeman

Tan A. 1983. Sayısal Taksonomik Yöntemlerle Varyasyonun Saptanmas1. EBZAE, 30. Menemen.

Tan AS. 1993. Ayçiçeğinde (Helianthus annuus L.) melez varyete (F1) ıslahında kendilenmiş hatların çoklu dizi (Line x Tester) analiz yöntemine göre kombinasyon yeteneklerinin saptanması üzerine araştırmalar. Doktora tezi. E.Ü. Zir. Fak. Fen Bil. Ens. Tarla Bit. Ana Bil. Dalı. Bornova - İzmir.

Tan A. 2000. Biodiversity conservation. Ex situ and in situ conservation: A case in Turkey. In: Watanabe K, Komamine A, eds. Challenge of plant and agricultural sciences to the crisis of biosphere on the Earth in the 21st Century. Eurekah, Texas.

Tan A. 2002. In situ on-farm conservation of landraces grown in North-Western Transitional Zone of Turkey. Final Report. TUBITAK-TOGTAG-2347. Ankara: Tubitak.

Tan A. 2009. Türkiye Geçit Bölgesi Genetik Çeşitliliğinin In situ (Çitçi Sartlarında) Muhafazası olanakları. Anadolu J AARI 19(1): $1-12$.

Tan A. 2010a. Türkiye Bitki Genetik Kaynakları ve Muhafazası. Anadolu J AARI 20(1): 7-25.

Tan A. 2010b. State of plant genetic resources for food and agriculture. second report of turkey on conservation and sustainable utilization of plant genetic resources for food and agriculture. Bornova, Izmir, Turkey: Aegean Agricultural Research Institute Publication No. 141, Meta Basım (Turkish and English). ISBN: 978-975-407-292-1. Available from ftp:// ftp.fao.org/ag/agp/countryreports/TurkeyFINALCR.pdf.

Tan AS. 2010a. Sunflower (Helianthus annuus L.) researches in Aegean Region of Turkey. 8th European Sunflower Biotechnology Conference. SUNBIO 2010. 1-3 March 2010, Antalya, Turkey. Helia 53: 77-84.

Tan AS. 2010b. Performance of some oilseed and confectionary type of sunflower (Helianthus annuus L.) varieties Aegean Region of Turkey. 8th European Sunflower Biotechnology Conference. SUNBIO 2010. 1-3 March 2010, Antalya, Turkey. Helia 53: 91-100.

Tan AS. 2010c. Identification of rust (Puccinia helianthi Schw.) races of sunflower (Helianthus Anuus L.) in Turkey. 8th European Sunflower Biotechnology Conference. SUNBIO 2010. 1-3 March 2010, Antalya, Turkey. Helia 53: 181-190.

Tan AS. 2014. Bazı Yağlık Hibrit Ayçiçeği Çeşitlerinin Menemen Ekolojik Koşullarında Performansları. Anadolu J AARI 24(1): $1-20$.

Tan A, Tan AS. 1998a. Database management systems for conservation of genetic diversity in Turkey. In: Zencirci N, Kaya Z, Anikster Y, Adams WT, eds. The Proceeding of International Symposium on In situ Conservation of Plant Genetic Diversity. 4 8 November, 1996. Antalya, Turkey.

Tan A, Tan AS. 1998b. Data collecting and analysis: For in situ, on farm, conservation. In: Jarvis DI, Hodghin T, eds. Strengthen the scientific basis of in situ conservation of agricultural biodiversity on-farm. Options for data collecting and analysis. Proc. of a workshop to develop tools \& procedures for in situ conservation on-farm, 25-29 August, Rome, Italy: IPGRI. Available from ftp:// ftp.fao.org/ag/agp/countryreports/TurkeyFINALCR.pdf.

Tan AS, Tan A. 2010. Sunflower (Helianthus annuus L.) Landraces of Turkey. Their collections conservation and morphometric characterization. 8th European Sunflower Biotechnology Conference. SUNBIO 2010. 1-3 March 2010, Antalya, Turkey. Helia 53: $55-62$.

Tan AS, Tan A. 2011. Genetic resources of sunflower (Helianthus annuus L.) in Turkey. International Symposium on Sunflower Genetic Resources. October 16-20, 2011. Kusadasi, Izmir, Turkey. Helia 34: 39-46.

Tan AS, Tan A. 2012. Characterization of sunflower genetic resources of Turkey. 18th International Sunflower Conference, Argentina, Feb 27 Marc-1 Feb 2012.

Tan AS, Aldemir M, Altunok ve A, Tan A. 2013a. Characterization of Confectionary Sunflower (Helianthus annuus L.) Genetic resources of denizli and erzurum provinces. Anadolu J AARI 23(1): 5-11.

Tan AS, Aldemir M, Altunok ve A, Tan A. 2013b. Characterization of confectionary sunflower (Helianthus Annuus L.) Land races of Turkey. International Plant Breeding Congress. 10-14 November 2013, Antalya, Turkey.

Tan AS, Altunok A, Aldemir M. 2016a. Oilseed and confectionary sunflower (Helianthus annuus L.) landraces of Turkey. 19th International Sunflower Conference, Edirne, Turkey. 29 May-3 June 2016, pp. 556-566.

Tan AS, Aldemir M, Altunok A. 2016b. Oilseed and confectionary sunflower (Helianthus annuus L.) researches in Aegean Agricultural Research Institute (AARI). 19th International Sunflower Conference, Edirne, Turkey. 29 May-3 June 2016, pp. 527-534.

Tan AS, Altunok A, Aldemir M, Yılmaz I, Kartal H, Peksüslü A, Aykas L. 2016c. Türkiye Endüstri Bitkileri Genetik Kaynakları. Anadolu J AARI 26(1): 28-45. 
Tan AS, Aldemir M, Altunok A. 2017a. Bazı Çerezlik Ayçiçeği Çeşit Adaylarının Menemen, İzmir Ekolojik Koşullarında Verim Potansiyelleri. ETAE Dergisi. Anadolu J AARI 2017(1): 1-16.

Tan AS, Tan A, Aldemir M, Altunok A. 2017b. Ege Bölgesi Ayçiçeği Araştırmaları Projesi. 2017 Yılı Gelişme Raporu (Sunflower Research Project for Aegean Region Annual Report, 2017). Ege Tar. Ara. Ens. Menemen. İzmir.

Tan AS, Tan A, Aldemir M, et al. 2017c. Endüstri Bitkileri Genetik Kaynakları Projesi. 2017. Yılı Gelişme Raporu (Industrial Crops
Resources Research Project. Annual Report, 2017). Ege Tarımsal Arastirma Enstitüsu (Aegean Agriculture Research Institute). Menemen, Izmir, Turkey.

Tanksley SD, McCouch SR. 1997. Seed banks and molecular maps: Unlocking genetic potential from the wild. Science 277: 1063-1066.

Zeven AC, de Wet JMJ. 1982. Dictionary of cultivated plants and their regions of diversity. The Netherlands: Pudoc, Wageningen, pp. 200 .

Cite this article as: Tan AS, Kaya Y. 2019. Sunflower (Helianthus annuus L.) genetic resources, production and researches in Turkey. OCL 26: 21 . 